The average age of the remaining sixty men when invalided was 21 years, 8 months, and their average service two years and five months. The number under one year's service was ten. In eighteen cases the ear trouble was stated by the men to have been noticed " from childhood", and in addition to these eighteen cases, seventeen gave a fairly good history of the disease before enlistment.

This leaves twenty-seven cases as probably arising after enlistment. Of these twentyseven cases, three were said to be due to bathing; two were said to follow malaria; in seventeen no cause could be suggested; four were said to be due to injury (two to "blow on the head." one to " rifle discharging" and one to "fall down a hatchway") of the long service men, one was said to be due to "malaria", and in the others no cause could be suggested.

In thirty-seven cases both ears were affected, in ten the right, and in fifteen the left only. There was discharge from the external meatus from both ears in twenty, from the right ear only in fourteen, and from the left only in eighteen. In twenty-two there was perforation of the tympanic membrane in both ears, in thirteen in the right only, and in seventeen in the left only. In seven deafness was very marked without either discharge or perforation.

Note-Forty-eight of the men were infantrymen, twelve cavalrymen, and two garrison drummers.

Such short service as these men have given in return for their expensive training is obviously a very bad investment for the State. I think when the facts given are thoughtfully considered, my brother officers will agree that a remedy is much needed.

I am of opinion that more care must be exercised in testing the hearing of the recruits and in examining their ears with the auroscope-which should be invariably used-and in all cases of doubt they should be seen by an aural specialist. If there are many of a doubtful character more aural specialists may have to be asked for, but, if the remedy would even halve this terrible loss, the time and money would be well spent.

\title{
THE DEATH OF GENERAL GORGAS - AT MILLBANK
}

\author{
Lieutenant-Colonel ETHELWALD E. VELLA, M.D., \\ F.R.C.Path., M.I. Biol., R.A.M.C. \\ Department of Pathology, Royal Army Medical College, Millbank
}

FifTY years ago, in the early hours of the 4th July 1920, Surgeon-General William Crawford Gorgas of the United States Army Medical Department died at The Queen Alexandra Military Hospital, Millbank. 
SURGEON GENERAL WILLIAM CRAWFORD GORGAS, K.C.M.G., M.D., D.Sc., LL.D.

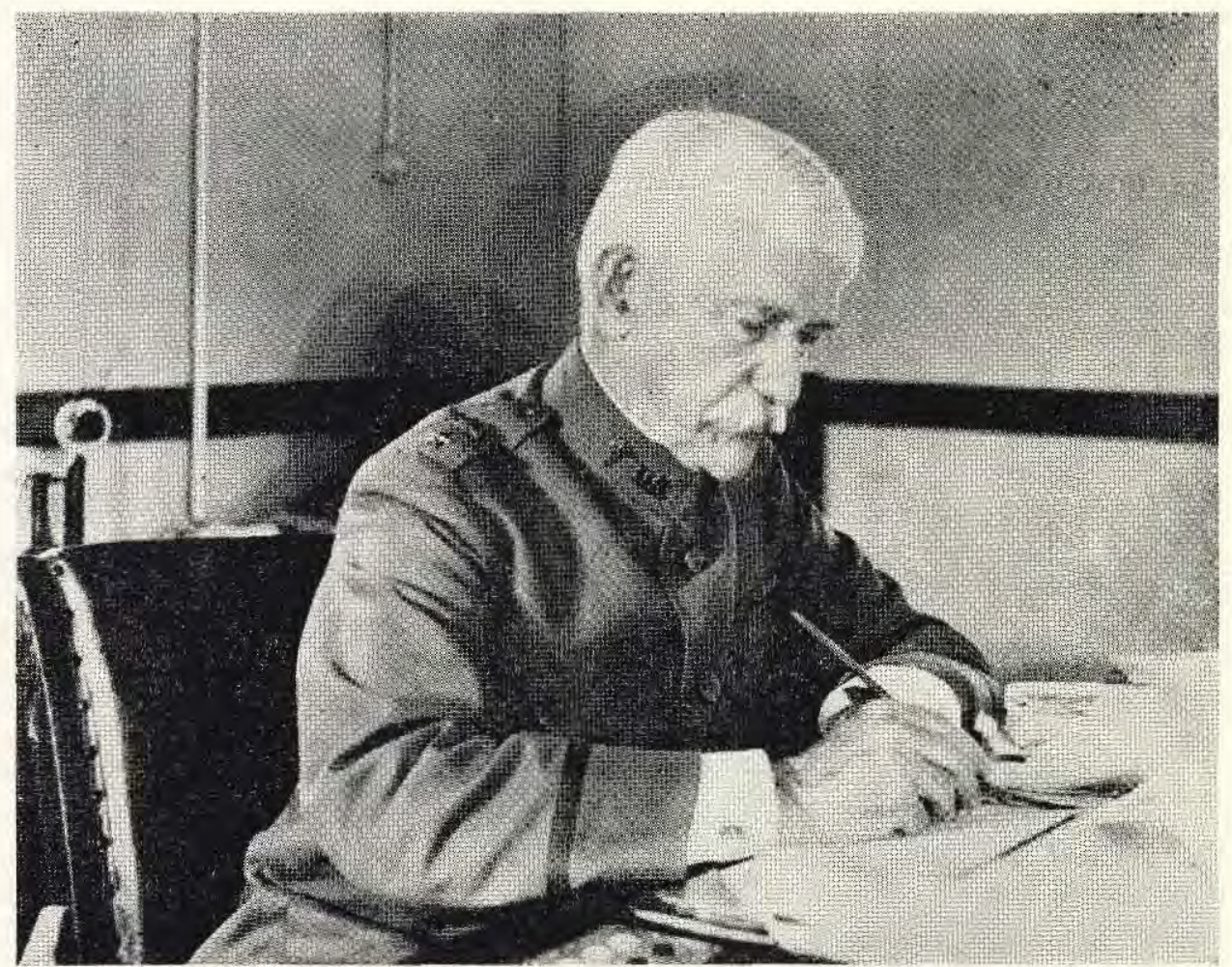

(Photograph by courtesy of the National Library of Medicine, Bethesda, Md.)

He will be remembered by many as the man who helped to make possible the construction of that great inter-oceanic seaway the Panama Canal, which was officially opened on the 20th November 1915. When the United States Government undertook the construction of the Canal, Gorgas was appointed Chief Sanitary Officer of the Canal Zone. He fulfilled all that was expected of him, and more; he turned that most pestiferous district of the world, the natural home of malaria, yellow fever, typhus and dysentery into a healthier place, for the American engineers constructing the canal, than the City of New York.

Amongst doctors practising tropical medicine, especially those working in the field of preventive medicine, his name will be inevitably linked with yellow fever, and mentioned whenever this disease is talked about. He fought and defeated yellow fever whenever he encountered it; his first signal victory being in Cuba where he was one of the first men to eradicate an insect borne disease by a well planned attack based upon the knowledge of the habits and life-history of the vector, thus breaking the chain of infection-patient-mosquito-patient. For this achievement a Special Act of Congress 
was passed promoting him to Colonel and appointing him Assistant Surgeon General in the U.S. Army Medical Department.

Later, as Surgeon General during the first World War of 1914-1918, Grorgas reorganised the structure of the U.S. Army medical service with great foresight and success.

Two years after the Armistice, true to his life-long ambition to ferret out and defeat Yellow Fever, he was on his way to West Africa to investigate an epidemic which was reported to have broken out in a vast region of the Dark Continent, stretching from Senegal to the Congo. He was taken ill while in London on 30 May 1920 suffering from a paralytic stroke, and on the advice of Sir John Goodwin, the Director-General of the (British) Army Medical Service, he was admitted to The Queen Alexandra Military Hospital, Millbank.

Mrs. Gorgas was with her husband when he was taken ill and the following incident, which impressed her deeply, is best described in her own words. "One morning on going to the hospital, the usual calm and ordinary routine seemed a bit upset. An undercurrent of excitement pervaded the atmosphere, which aroused my curiosity. Dr. Gorgas was steadily improving, and I did not associate him in any way with the stir and bustle. Later, the head nurse, Sister Erdley, beckoned to me from the hall. I went to her, and she told me with very evident pleasure that the King was coming that morning to see General Gorgas. Fearing to excite him, they had deemed it wise to say nothing until soon before the King was expected.

'Will you tell General Gorgas now', said Sister Erdley, 'that we are expecting the King at any moment'.

I did so at once, and it did me a world of good to see the Doctor's look of surprise and pleasure. The disappointment he had felt in not being able to keep an appointment with the King was swept aside in a moment. To Sir John Goodwin, the King had said, when he heard of Dr. Gorgas's illness, 'If General Gorgas is too ill to come to the palace to see me, I shall go ot the hospital to see him.'

On that to me never-to-be-forgotten morning the invalid, the dominant figure in the room bare to monastic simplicity, showed no trace of illness. There was a slight flush on his cheeks, the white pillows at his back and the faint touch of blue in his immaculate invalid's attire threw into relief the fine head capped by the heavy crown of snow-white hair.

By special request of His Majesty I was present at the interview. The King came in quietly 'without fuss or feathers' as he had expressed himself to Sir John Goodwin, accompanied only by Sir John and his Equerry in Waiting. The attending physicians followed with the Matron, Sister Humphrey, and Sister Erdley, the little group standing a few paces back.

The King spoke to us in a delightfully simple way. His cordiality charmed us. The smile which always drew people to him hovered about the Doctor's lips as the King talked with him, expressing distress at his illness and earnest wishes for a speedy improvement in his condition.

His Majesty talked at considerable length of the work which had been carried out in Panama and Cuba, and especially of the subject of yellow fever and the extermination of that disease. He thanked Dr. Gorgas for all the help which he had given the British 
Army in sending medical officers and nurses to work for the British forces, and assured him that this help had been of immense value and was deeply appreciated.

Then, taking from his Equerry the insignia of Knight Commander of the Most Distinguished Order of St. Michael and St. George, the King presented it to Dr. Gorgas saying, ' General Gorgas, it gives me very great pleasure to present you with the insignia of this Order; and believe me, I very sincerely appreciate the great work which you have done for humanity-work in which I take the greatest interest'.

Nothing could have been more impressive, more touching, than this simple ceremony!

On the death of General Gorgas The Royal Society of Medicine made plans for the funeral service, but the King ordered a State funeral with full Military honours. This took place on the 9 July 1920, the coffin was taken from The Queen Alexandra Military Hospital, borne on a gun carriage of the Royal Horse Artillery, while the following army medical officers acted as pall-bearers.

Major-General Sir William Grant Macpherson
Major-General Alfred Percy Blenkinsop
Major-General George Bradshaw Stanistreet
Colonel Oliver Long Robinson
Colonel Harry Alexander Hinge
Colonel James Robert McMunn

Headed by the band of the Coldstream Guards, and while guns in Hyde Park boomed their farewell salute, the funeral cortege proceeded slowly along the Embankment to St. Paul's Cathedral where the service was held. The Cathedral was crowded with many representatives of governments and academic institutions. The King was represented by Lieutenant-General Sir John Goodwin, the D.G.A.M.S.; the Duke of Connaught, Colonel-in-Chief of the Royal Army Medical Corps by Colonel Sir Edward Worthington; Sir David Bruce represented The Royal Society.

The coffin was later brought back to The Queen Alexandra Military Hospital, whence it was taken to Southampton, and then by ship to the United States. The body lay in state for four days in Washington, and now lies buried in Arlington, near Washington, the national cemetery of the U.S. Navy and Army.

It is fitting to conclude the description of this historic and unique occasion in the history of The Queen Alexandra Military Hospital, with this tribute to General Gorgas by one of his biographers.

" Gorgas was princely - with the simplicity of a child. He loved his fellow men to the extent that he saw good in all, and by his tolerant sympathy, he drew men to him, who by thousands, claimed him as a friend.

He commanded his great armies of aids, in his civil work as well as in his war work, not by autocratic methods, but by power of persuasion, and by the example of his own industry.

In his official life, in his social life, and in his family life, he was the true friend of mankind, the courteous gentlemen ".

BIBLIOGRAPHY

Gorgas, M. B. and Hendrick, B. J. (1924). William Crawford Gorgas. His Life and Work, Lea \& Febiger, Philadelphia.

MarTin F. H. (1923). Surg. Gynec. Obstet. 37, 558. 